\title{
KRIS KRISTOFFERSON/JOHN HOLT-'HELP ME MAKE IT THROUGH THE NIGHT’
}

A s with all the contributors here, my chosen song comes from fieldwork. I spent time in an urban UK mental health community setting, a place which nobody has to attend (it is not part of the statutory psychiatric system), but where people choose to spend time to gain various kinds of support-formal and informal-whilst in other respects living independently despite (in most cases) having a psychiatric diagnosis. Most service users with whom I spent time were male, over forty, long-term unemployed, living on the economic edge, ever fearful about having their benefits withdrawn, and diagnosed with some form of mental illness, most commonly paranoid schizophrenia. My primary reason for being there was to participate in and observe the various interactions around the provision of music in general and music therapy in particular.

I am a music therapist, and I'd had previous interactions with this setting (and many of its service users) over a number of years of working in the local area, including at the local psychiatric hospital. This was helpful in terms of negotiating access but also exposed me to (and embroiled me in) conflicts from which I might have been relatively separated had I been there purely in my 'professional' role. I have chosen this particular song as it reminds me of this period, bringing back many warm memories, but also encapsulating musically the conflicts which were integral to the challenge of fieldwork experience.

Music therapy is a professionalised practice in the UK; it is often described in pseudomedical 'treatment' terms, yet the practice of music therapy looks very different from that of medicine. Music therapists actively make music with their 'clients', often improvisationally, and so things are likely to be different every time. Music is also rather different from antipsychotic medication in that, as Small (1998) pointed out, music is a social act-and in this case a collaborative act-rather than simply a thing which is done. And as DeNora (1986) says, it's also a means by which social and cultural work gets done.

Another reason why music therapy doesn't quite fit the medical or psychotherapeutic narratives applied to it is that music leaks-it travels through walls. People sing tunes that they might have been only vaguely aware of hearing earlier. As a marker of cultural identity, music also brings significant potential for conflict, and nowhere more so than in an urban environment characterised by significant cultural diversity. Many people here have strong (and often lifelong) experiences of being disempowered, and subsequent to receiving a psychiatric diagnosis many have also had the experience of being deprived of their liberty (in the form of being 'sectioned' and hospitalised under the Mental Health Act), receiving treatment against their will (often with physical force), and of having their cultural identity overlooked in order that they should become a 'good patient' within the psychiatric system. In contrast, this place (started by service users themselves) seemed to present people with an opportunity to 'be themselves'; reclaiming cultural identity seemed to be an important aspect of doing this, and songs a means of doing so. 
Music in general and songs in particular were everywhere. Daily life hinged on lunchtime; a small kitchen offered work experience to a group of service users in preparing food throughout the morning and then everyone would eat lunch together (with no medical-style separation between service users and workers). The radio in the kitchen was switched on first thing in the morning and switched off last thing in the evening, and there was considerable competition for control of the tuning button. Lunchtimes were sometimes testily silent and sometimes fractious, but the music on the radio helped to smooth this over to some extent.

Songs played a significant role within formal music therapy sessions too. Sometimes these were songs developed as part of the therapy process, but more often people would bring well-known songs into their sessions. In this way they seemed to be asserting themselves culturally by expressing something of what mattered to them musically.

People would also sit around in the drop-in (or outside at the smoking table) trading songs-either singing them at each other, or talking passionately about their musical commitments, and in the process making claims to cultural identity and influencing people's conceptions of each other. I was often part of these conversations; they gave me perspectives on people's lives that it would have been hard to acquire from more formal encounters. At the same time, this kind of self-revelation often felt highly personal and led to demands for me to justify my role as well as an expectation of reciprocity in terms of sharing my own songs. Yet it was the role of songs in more communal music-making that really gripped me.

Given the significance of lunch-lowpriced hot food already prepared-it was unsurprising that many service users came in primarily to have lunch and then went home again. When they did stay, many seemed lethargic, with little observable interaction with others. This was identified as problematic both by more active service users and by workers. What could be done about this? I was challenged to help start a communal pre-lunch music group in the large open communal space. This quickly turned into a 'karaoke group'-karaoke in the sense that I became the 'karaoke machine', perceived as more or less able to accompany (on instruments) whatever songs people wanted to sing. There were actually significant restrictions on my ability to do this, stemming both from my non-universal knowledge of songs and from my cultural limitations in terms of range of musical styles, but we muddled through as best we could, with considerable good-will exhibited on all sides. However, there were also frequent disputes-over whose turn it was to choose a song, over what kind of repertoire was acceptable, and over how a song should be sung. My chosen song exemplifies this.

Eric, who described himself as 'Caribbean through and through', requested 'Help me make it through the night'. I knew it as a rather static but intense love song - as in the original hit version by Sammi Smith and a well-known duet version featuring the song's writer Kris Kristofferson and Rita Coolidge. However, when I started playing an introduction in this style, Eric's reaction came swiftly:

'Woah! Hold it there! What the $\mathrm{F}^{* * *}$ you think you're doin'?'

In the animated discussion that followed, it turned out that for Eric this was an upbeat reggae song-he knew it in John Holt's cover version. Eric was genuinely and almost violently affronted that anyone would do this to a perfectly fine reggae song. This was a profoundly uncomfortable moment: I had genuinely offended Eric's sensibilities. Others present knew the original version and tried to 
intervene to persuade him that both versions were acceptable, but he wasn't having any of it.

I suggested that Eric show me how he wanted the song to feel-using irritated arm gestures, he vigorously demonstrated the 'skank' that characterises reggae and also showed the tempo he wanted. Following his gestures really helped me to pick up his feel; it also gave us a sense of being joined together physically after the rupture of confrontation. Having initially seemed to be imposing my version of the song, now I was clearly physically committed to being led by him into an understanding of how this song 'should' be performed. As the introduction was re-played reggae style, he seemed first mollified and then able to strut his reggae stuff in front of the others. I found myself really straining to ensure this sounded as reggae as I could make it at the piano-keeping the skank going in my right hand, providing a nice solid bass in my left hand, and catching his eye as the song went on for signs of approval.

Eric tended to want to sing song after song after song-always loudly, and always fast-but he also wanted to be a seen as a good singer and to have a sense of 'improving'. I encouraged him to think about variety in his singing, and this song became an example of how songs could be performed in different ways. Eric loved singing in front of others in the karaoke group and being praised for his singing, so the idea of having a wider appeal was a powerful one for him. This was probably the allure that persuaded him to try it in more of a country style. With me encouraging him musically and supporting his every experimental move, Eric began to be able to sing this song in other ways, including sometimes much more quietly and slowly than was his norm. For a man whose presentation of self in life was so 'in your face' and relentless, this seemed a real shift.
Some months later, a new member of the lunchtime group said he didn't want to sing, but he liked country music. Eric piped up, 'We know a country song, don't we?' and (having first whispered instructions into my ear) gave a performance of 'Help me make it through the night', country style. At the end there was applause, whooping and cheering because he had pulled it off with such presence; another of the 'old boys' shouted out provocatively 'I thought it was a reggae song, man?'

'Ah well,' responded Eric. 'You gotta be versatile. Now the real thing.' And we did it again, reggae-style.

The processing of this conflict was a thoroughly musical matter and a useful process for all concerned, ethnographer included. This process had much to do with accepting the validity of a "strange" version of the song, not just on a theoretical level, but as part of someone else's lived experience which has the potential to be shared, at least to some extent. This matters for all of us, but perhaps especially in the context of chronic mental illness, where people tend to get locked into set ways of being and thinking, not least as a defence for the protection of a viable sense of self. I encountered many instances when songs and even styles of music were a cultural ground where compromise was possible and where people might find commonality, but also when songs became the conduit for people to discover a certain flexibility in themselves.

This is also a useful lesson for the ethnographer, especially in a relatively familiar field, where the challenge is always to render the familiar strange. Becoming unintentionally embroiled in the active disputing of songs enabled me to experience the apparently familiar as uncomfortably unfamiliar, and I would argue that this is where my music therapist and 
ethnographer roles converged. Much observing, following and learning was demanded of me in each musical moment. I too learned an essential degree of flexibility and responsiveness to what turned out to be strange indeed.

Eric - and Kris Kristofferson and John Holt-collaboratively demonstrated to me something central to DeNora's 'everyday life' perspective on music sociology (2003): namely, that music is not simply something symbolic or representational, but rather a form of social action replete with affordances and opportunities for appropriation. Similarly, music therapy can be considered not so much as something that a music therapist does, but rather as shared endeavour in the deployment of cultural identity and 'musicianship in the world' as tools for resourceful living. As such, the ethnographer's attitude (of rendering the familiar strange and of learning by immersion how people make use of their cultural tools) underpins the doing of music therapy. I am a fieldworker, and music is my field.

\section{REFERENCES}

DeNora, Tia 1986. How is extra-musical meaning possible? Music as a place and space for 'work'. Sociological Theory 4 (1): 84-94.

DeNora, Tia 2003. After Adorno: Rethinking Music Sociology. Cambridge: Cambridge University Press.

Holt, John 1973. 'Help Me Make it Through the Night'. Composed by Kris Kristofferson. 1000 Volts of Holt. Trojan Records: United Kingdom.

Small, Christopher 1998. Musicking. Hanover: Wesleyan University Press.

SIMON PROCTER

DIRECTOR OF MUSIC SERVICES

EDUCATION, RESEARCH AND PUBLIC

AFFAIRS

NORDOFF ROBBINS

simon.procter@nordoff-robbins.org.uk 